\title{
EKOLITERASI SISWA MELALUI KEGIATAN PENGELOLAAN SAMPAH BERBASIS GROUP INVESTIGATION di SMAN 1 MOYO UTARA TAHUN PELAJARAN 2017/2018
}

\author{
Diah Wardaniah ${ }^{1}$, Indah Dwi Lestari ${ }^{2}$, Eryuni Ramdhayani ${ }^{3}$ \\ Program Studi Pendidikan Biologi Fakultas Keguruan dan Ilmu Pendidikan \\ Universitas Samawa, Sumbawa Besar
}

\begin{abstract}
ABSTRAK
Penelitian ini bertujuan untuk mengetahui ekoliterasi siswa setelah melakukan kegiatan pengelolaan sampah berbasis group investigation di SMAN 1 Moyo Utara Tahun Pelajaran 2017/2018. Dari pengamatan menunjukkan ekoliterasi siswa masih rendah. Hal ini terlihat dari sikap ketidakpedulian siswa terhadap lingkungan sekolah yang ditunjukkan dengan perilaku masih banyaknya siswa yang membuang sampah sembarangan, terdapat sampah berserakan di dalam dan di luar kelas.

Metode yang digunakan dalam penelitian ini adalah metode penelitian kualitatif deskriptif, metode ini dimaksudkan untuk memperoleh informasi mengenai ekoliterasi siswa melalui kegiatan pengelolaan sampah berbasis group investigation di SMAN 1 Moyo Utara Tahun Pelajaran 2017/2018 secara mendalam dan komprehensif. Subyek penelitian ini adalah kelas X-MIA 2 yang terdiri dari 32 responden. Data yang digunakan ialah data primer dan sekunder yang diperoleh dari tekhnik obseevasi, wawancara dan kuisioner (angket). Tekhnik analisis data yang digunakan dalam penelitian ini adalah reduksi data, penyajian data dan penarikan kesimpulan. Dari hasil penelitian ini menunjukkan bahwa ekoliterasi siswa setelah melakukan kegiatan pengelolaan sampah berbasis group investigation di SMAN 1 Moyo Utara Tahun Pelajaran 2017/2018 dikategorikan cukup, hal tersebut terlihat dari indikator pengetahuan siswa dikategorikan baik sebanyak 28 responden (90\%), indikator kesadaran siswa dikategorikan cukup terlihat pada jawaban 'selalu' sebanyak 15 responden (41\%), 'jarang' sebanyak 8 responden (27\%), kadang-kadang sebanyak 5 responden (17\%), tidak pernah sebanyak 4 responden (15\%), dan aplikasi siswa dikategorikan cukup sebanyak 17 responden (52\%). Serta hasil lembar observasi dari kegiatan tersebut dikategorikan cukup. Dari hasil penelitian ini, maka disarankan siswa SMA Negeri 1 Moyo Utara agar tetap menjaga dan memelihara kebersihan lingkungan. Manfaat dari pentingnya pengelolaan sampah dapat mewujudkan pribadi yang sehat dan lingkungan yang bersih.
\end{abstract}

Kata Kunci : Ekoliterasi, Pengelolaan Sampah, dan Group Investigation (GI).

Fakultas Keguruan dan Ilmu Pendidikan 


\section{PENDAHULUAN}

Pendidikan nasional berfungsi mengembangkan dan membentuk watak serta peradaban bangsa yang bermartabat dalam rangka mencerdaskan kehidupan bangsa, bertujuan untuk mengembangkan potensi peserta didik agar menjadi manusia yang beriman dan bertakwa kepada Tuhan Yang Maha Esa, berakhlak mulia, sehat, berilmu, cakap, kreatif, mandiri, dan menjadi warga negara yang demokratis serta bertanggung jawab. Berdasarkan rumusan tujuan pendidikan tersebut, jika disimpulkan maka tujuan pokok pendidikan adalah agar siswa dapat menjadi pribadi yang pandai dan baik perilakunya yang berorientasi pada peningkatan bukan hanya aspek pengetahuan saja, tetapi juga memadukan unsur sikap dalam proses pembelajaran. Realitanya pada saat ini unsur sikap kerap kali kurang mendapat perhatian dari guru sehingga ketika proses pembelajaran, siswa tidak dibiasakan untuk mengembangkan aspek sikap peduli terutama terhadap lingkungan.

Berbicara mengenai sikap peduli terhadap lingkungan, dalam Pendidikan Biologi kesinambungan antara makhluk hidup dan alam yang merupakan faktor terpenting dalam menjaga kelestarian lingkungan. Salah satunya proses pembelajaran tentang ekoliterasi atau sering disebut juga kecerdasan ekologis, berasal dari kata Yunani oikos (habitat) dan logos (ilmu). Kecerdasan ekologis bersifat kompleks. Kecerdasan tersebut didukung oleh unsur kognitif, afektif (sosial dan emosi), dan psikomotorik. Hasrat untuk menjaga lingkungan hidup didasari oleh pengetahuan tentang lingkungan. Kesadaran untuk menyelamatkan lingkungan yang rusak didasari oleh aspek afektif, sedangkan tindakan untuk menjaga kelestarian lingkungan menggambarkan aspek psikomotorik.

Adapun indikator ekoliterasi diantaranya yaitu aspek pengetahuan, kesadaran dan aplikasi. Peneliti memfokuskan ketiga indikator tersebut. Hal ini dikarenakan jika pengetahuan dan kesadaran yang rendah akan pentingnya menjaga lingkungan sekitar maka akan berakibat pada kerusakan lingkungan. Seperti apa yang diutarakan bahwa Berakhirnya abad ke 20, masalah lingkungan menjadi hal yang utama. Kita dihadapkan pada serangkaian masalah-masalah global yang membahayakan biosfer dan kehidupan manusia dalam bentuk-bentuk yang sangat mengejutkan yang dalam waktu dekat akan segera menjadi tak dapat dikembangkan lagi.

Dari hasil observasi dan wawancara peneliti kepada guru mata pelajaran Biologi untuk mengetahui ekoliterasi pada siswa SMAN 1 Moyo Utara. Hasil yang diperoleh setelah pengamatan menunjukkan ekoliterasi siswa masih rendah. Hal ini terlihat dari sikap ketidakpedulian siswa terhadap lingkungan sekolah yang ditunjukkan dengan perilaku masih banyaknya siswa yang membuang sampah sembarangan, terdapat sampah berserakan di dalam dan di luar kelas terutama kertas. Padahal di dalam kelas terdapat daftar piket kebersihan yang seharusnya siswa membersihkan kelas dan halaman depan kelas. Kemudian ketika pembelajaran akan dimulai suasana di kelas berantakan, mereka baru akan 
memungut sampah ketika guru harus menegur terlebih dahulu. Ketika membuang sampah pun mereka asal membuang saja tanpa terlebih dahulu memilah antara sampah organik dan non organik, hal ini disebabkan karena tidak tersedianya bak sampah terpisah antara organik dan non organik.

Berdasarkan kondisi di atas, harus adanya perbaikan melalui kegiatan pengelolaan sampah berbasis group investigation untuk mengetahui gambaran capaian ekoliterasi siswa di sekolah. Sehingga, nantinya diharapkan mampu meningkatkan peran siswa dalam menjaga lingkungan sekitarnya terutama disekolah itu dapat memberikan dampak positif bagi terciptanya keadaan lingkungan yang bersih, nyaman dan sehat serta memperkuat aset sosial siswa pendidikan biologi yaitu mendorong siswa untuk mengembangkan mekanisme pembelajaran transformatif yang mampu meningkatkan kemitraan, kerjasama dan kolaborasi dengan baik. Selain dengan tindakan secara langsung dapat juga diterapkan dalam kegiatan pendidikan formal, tentunya dengan berbagai metode serta teknik yang dikembangkan oleh pendidik dengan cara yang terbaik agar mendapatkan hasil yang optimal. Oleh karena itu, maka penulis tertarik untuk meneliti tentang peran siswa dalam memahami lingkungan sebagai alternatif pembelajaran yang dapat mengembangkan sikap ekoliterasi dengan judul "Ekoliterasi Melalui Kegiatan Pengelolaan Sampah Berbasis Group Investigation".

\section{METODE PENELITIAN}

Metode yang digunakan dalam penelitian ini adalah metode penelitian kualitatif deskriptif, metode ini dimaksudkan untuk memperoleh informasi mengenai ekoliterasi siswa melalui kegiatan pengelolaan sampah berbasis group investigation di SMAN 1 Moyo Utara Tahun Pelajaran 2017/2018 secara mendalam dan komprehensif. Subyek penelitian ini adalah kelas X-MIA 2 yang terdiri dari 32 responden. Data yang digunakan ialah data primer dan sekunder yang diperoleh dari tekhnik obseevasi, wawancara dan kuisioner (angket). Tekhnik analisis data yang digunakan dalam penelitian ini adalah reduksi data, penyajian data dan penarikan kesimpulan.

\section{HASIL DAN PEMBAHASAN}

Penelitian ini akan dilaksanakan pada bulan Mei selama kurang lebih 3 Minggu lebih bertempat di SMAN 1 Moyo Utara tentang ekoliterasi siswa melalui kegiatan pengelolaan sampah berbasis group investigation. Adapun subyek dari penelitian ini adalah seluruh siswa kelas X-MIA 2 yang terdiri dari perempuan sebanyak 17 orang dan laki-laki sebanyak 7 orang. Berdasarkan hasil kegiatan pengelolaan sampah berbasis group investigation terhadap 32 responden, maka hasil yang diperoleh dari setiap item lembar observasi yaitu sebanyak 25 responden (78\%) melakukan kegiatan pemilahan sampah (A) dengan baik, sebanyak 30 responden (94\%) melakukan kegiatan penampungan sampah (B) 
sesuai dengan tempatnya, sebanyak 21 responden (66\%) melakukan kegiatan pengangkutan sampah (C) yang telah disediakan, dan sebanyak 16 responden (D) melakukan cara pengelolaan sampah yang benar. Hal ini menunjukkan bahwa siswa kelas X-MIA 2 sudah cukup baik dalam melakukan pengelolaan sampah yang benar terlihat dari persentasi gambar 4.2 grafik hasil observasi, meliputi pemilahan sampah (organik dan anorganik), penampungan sampah pada wadah yang berbeda, pengangkutan sampah dan pengelolaan sampah menjadi kompos serta membuat kerajinan tangan dari sampah selama kegiatan berlangsung. Hal tersebut berarti sesuai dengan pengelolaan sampah yang benar dilakukan dengan cara melakukan pemilahan sampah oganik dan anorganik pada wadah yang berbeda dan menerapkan konsep 3R. Berdasarkan data tersebut, menunjukkan bahwa dengan kegiatan pengelolaan sampah berbasis group investigation yang dilakukan telah menggambarkan ekoliterasi pada siswa. Ketercapaian ekoliterasi siswa dapat diidentifikasi dengan tiga indikator yaitu pengetahuan, kesadaran dan aplikasi.

Berdasarkan hasil analisis yang telah dilakukan terhadap 32 responden kelas X-MIA 2 di SMA Negeri 1 Moyo Utara menunjukkan bahwa tingkat pengetahuan responden tentang pengelolaan sampah dengan kategori baik cenderung lebih banyak daripada responden yang memiliki pengetahuan dengan kategori cukup dan kurang, hal ini dapat dilihat pada gambar 4.3 di atas, yang memperoleh nilai 'Benar' sebanyak 28 responden (90\%) berarti tingkat pengetahuan baik, dan yang memperoleh nilai 'Salah' sebanyak 4 responden $(10 \%)$ berarti tingkat pengetahuannya cukup tentang pengelolaan sampah. Umumnya siswa sudah mengetahui secara jelas pengertian sampah. Siswa sudah mampu menjelaskan dan memahami dengan baik pengertian sampah sebagaimana yang telah dijelaskan bahwa sampah adalah sebagian dari sesuatu yang tidak dipakai, tidak disenangi atau sesuatu yang harus dibuang, yang umumnya berasal dari kegiatan yang dilakukan oleh manusia (termasuk kegiatan industri), tetapi bukan biologis (karena human waste tidak termasuk didalamnya) dan umumnya bersifat padat. Secara umum pengertian sampah adalah barang atau benda yang dibuang karena tidak dipakai atau digunakan oleh pemiliknya.

Berdasarkan hasil analisis yang telah dilakukan terhadap 32 responden kelas X-MIA 2 di SMA Negeri 1 Moyo Utara menunjukkan bahwa tingkat kesadaran responden jawaban yang telah disediakan berupa pertanyaan SL berarti "selalu", J berarti "Jarang", KK berarti "Kadang-Kadang dan TP berarti "Tidak Pernah. Maka, dari gambar 4.3 di atas, dapat diketahui bahwa dari 32 responden yang mendominasi jawaban 'SL' sebanyak 15 responden (41\%), 'J' sebanyak 8 responden (27\%), 'KK' sebanyak 5 responden (17\%) dan 'TP' sebanyak 4 responden $(15 \%)$. Nyatanya dari hasil data tersebut, kesadaran siswa yang selalu dilakukan secara terus-menerus cenderung lebih banyak dibandingkan dengan jawaban jarang, kadang-kadang dan tidak pernah. Hal tersebut masih dikategorikan dalam kesadaran siswa masih cukup tentang pengelolaan sampah. 
Tentunya, hal ini tidak dapat dibiarkan begitu saja. Diantara mereka harus ada penggerak untuk bersama-sama saling mengingatkan dalam hal menuju masyarakat melek ekologis.

Berdasarkan hasil analisis yang telah dilakukan terhadap 32 responden kelas X-MIA 2 di SMA Negeri 1 Moyo Utara menunjukkan bahwa tingkat aplikasi responden yang memperoleh jawaban 'Ya' sebanyak 17 responden (52\%) berarti tingkat pengaplikasian dikategorikan baik, dan yang memperoleh jawaban 'Tidak' sebanyak 15 responden $(48 \%)$ berarti tingkat pengaplikasian dikategorikan cukup. Dari data tersebut, terlihat bahwa cenderung lebih banyak siswa yang dikategorikan pengaplikasiannya cukup, namun tidak sedikit juga yang pengaplikasiannya kurang. Hal ini disebabkan karena dari segi kognitif dapat dikatakan siswa kelas X-MIA 2 sudah baik namun dari segi kesadaran hanya beberapa persen saja yang dapat melakukannya secara terus-menerus sehingga hasil akhir dari aplikasinya tidak beda jauh. Hal ini menunjukkan bahwa harus adanya keceradasan ekologis yang bersifat kompleks. Sesuai dengan apa yang dijelaskan bahwa kecerdasan ekologis harus didukung oleh kognitif dalam hal ini pengetahuan, afektif dalam hal ini kesadaran dan psikomotorik dalam hal ini tindakan. Jika ketiga komponen ini telah dimiliki dengan baik, maka hasilnya pun akan terlihat memuaskan.

Disamping itu juga, disebabkan karena fasilitas yang ada di sekolah kurang memadai, kurangnya tempat sampah disetiap ruangan kelas, tumpukan sampah dibiarkan begitu saja tanpa penanganan yang cepat, hal ini dapat menimbulkan kesan tidak sehat, tidak nyaman bagi lingkungan, serta dapat menjadi tempat perkembangbiakan mikroorganisme pathogen atau serangga yang dapat menularkan berbagai penyakit. Ungkapan "bersih pangkal sehat" mengandung arti betapa pentingnya kebersihan bagi kesehatan manusia, baik perorangan, keluarga, masyarakat, maupun lingkungan.

Sebagaimana hasil lembar observasi, tabel dan wawancara maka peneliti dapat merekam gambaran ekoliterasi siswa. Hal ini membuktikan bahwa ekoliterasi siswa berhasil dilakukan melalui kegiatan pengelolaan sampah berbasis group investigation di SMAN 1 Moyo Utara sesuai dengan tahapan yang sudah dirancang oleh peniliti dengan hasilnya adalah siswa mengetahui perbedaan sampah organik dan anorganik secara nyata di lapangan, siswa dapat mengetahui konsep pengelolaan sampah melalui proses pembuatan pupuk kompos dari bahan organik yang ada di lingkungan sekolah untuk pemberian pupuk pada tanaman dan membuat hasil kerajinan tangan berupa vas bunga dan bingkai photo dengan kreativitas masing-masing secara berkelompok, siswa secara bersama-sama saling mengingatkan satu sama lain bahwa semua kegiatan manusia sehari-hari itu telah berdampak buruk pada lingkungan, siswa sadar akan pentingnya penjagaan lingkungan, siswa sadar pemahaman tentang kebersihan kurang baik jika aplikasinya tidak dilakukan dengan baik, dan siswa semakin sadar bahwa setiap lingkungan bersih akan menciptakan suasana yang nyaman. Hal tersebut tidak 
terlepas dari adanya komunikasi dan kerja sama team yang dibentuk untuk membangun keselarasan menjaga dan mencintai lingkungan demi terciptanya ekoliterasi.

\section{KESIMPULAN}

Berdasarkan hasil penelitian yang telah dilakukan di SMA Negeri 1 Moyo Utara Tahun Ajaran 2017/2018, maka dapat ditarik kesimpulan bahwa:

a. Hasil lembar observasi pada kegiatan pengelolaan sampah berbasis group investigation di SMA Negeri 1 Moyo Utara Tahun Ajaran 2017/2018 dikategorikan baik.

b. Pengetahuan siswa tentang pengelolaan sampah berbasis group investigation di SMA Negeri 1 Moyo Utara Tahun Ajaran 2017/2018 dikategorikan baik.

c. Kesadaran siswa tentang pengelolaan sampah berbasis group investigation di SMA Negeri 1 Moyo Utara Tahun Ajaran 2017/2018 dikategorikan cukup.

d. Aplikasi siswa tentang pengelolaan sampah berbasis group investigation di SMA Negeri 1 Moyo Utara Tahun Ajaran 2017/2018 dikategorikan cukup.

Penggunaan model pembalajaran group investigation dalam kegiatan pengelolaan sampah untuk merekam ekoliterasi siswa di SMA Negeri 1 Moyo Utara Tahun Ajaran 2017/2018 dikategorikan baik.

\section{DAFTAR PUSTAKA}

Capra, F. (2002). Jaring-Jaring Kehidupan. Yogyakarta: Fajar Pustaka Baru.

Lickana, T. (2012). Mendidik untuk Membentuk Karakter : Bagaimana Sekolah Dapat Memberikan Pendidikan tentang Sikap Hormat dan Bertanggung Jawab. Jakarta: PT Bumi Aksara.

Permadi, Guruh. (2011). Menyulap Sampah Jadi Rupiah. Surabaya: Mumtaz Media

Undang-Undang Sistem Pendidikan Nasional Nomor 20 Tahun 2013. 2005. Bandung: Nuansa Ilmu.

Supritana, N. (2016). Ecopedagogy: Membangun kecerdasan ekologis dalam Pembelajaran IPS. Bandung: Penerbit PT Remaja Rosdakarya.

Zulkifli, Arif. (2014). Dasar-Dasar Ilmu Lingkungan. Jakarta: Salemba Teknika. 